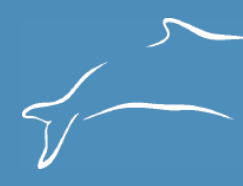

\title{
Cetaceans observed in Suriname and adjacent waters
}

\begin{tabular}{|c|c|}
\hline \multicolumn{2}{|c|}{ Article Info } \\
\hline Manuscript type & Article \\
\hline \multicolumn{2}{|l|}{ Article history } \\
\hline Received & 28 May 2013 \\
\hline Received in revised form & 16 September 2013 \\
\hline Accepted & 30 September 2013 \\
\hline Available online & 17 August 2015 \\
\hline \multicolumn{2}{|c|}{$\begin{array}{l}\text { Keywords: Cetacean diversity, Guianas, platform of opportunity, } \\
\text { Wider Caribbean Region }\end{array}$} \\
\hline \multicolumn{2}{|c|}{ Responsible Editor: Federico Riet } \\
\hline $\begin{array}{l}\text { Citation: De Boer, M.N. } \\
\text { Suriname and adjacent wa } \\
\text { Mammals 10(1): 2-19. htt }\end{array}$ & $\begin{array}{l}\text { 15) Cetaceans observed in } \\
\text { Latin American Journal of Aquatic } \\
\text { dx.doi.org/10.5597/lajam00189 }\end{array}$ \\
\hline
\end{tabular}

\author{
Marijke Nita de Boer ${ }^{\dagger, * *}$ \\ Wageningen IMARES, Institute for Marine Resources and Ecosystem \\ Studies, Den Burg, The Netherlands \\ ¥ Seven Seas Marine Consultancy, P.O. Box 11422, 1001 GK Amsterdam, \\ The Netherlands \\ ${ }^{*}$ Corresponding author, e-mail: marijkedeboer@sevenseasmarine.nl
}

Abstract. Very little information exists about the cetaceans in the Guianas: Suriname and its neighboring countries Guyana and French Guiana. During a dedicated cetacean survey carried out from a geophysical seismic survey vessel in the offshore waters of Suriname (May-September 2012), the occurrence of 13 cetacean species was documented and of those, 11 were newly documented for this area. The species observed by the author included sperm whale (Physeter macrocephalus), Bryde's whale (Balaenoptera edeni), false killer whale (Pseudorca crassidens), melon-headed whale (Peponocephala electra), roughtoothed dolphin (Steno bredanensis), long-beaked common dolphin (Delphinus capensis), Fraser's dolphin (Lagenodelphis hosei), pantropical spotted dolphin (Stenella attenuata) and spinner dolphin (Stenella longirostris). During transit to the survey area (Trinidad to Suriname) incidental sightings were recorded which included common bottlenose dolphin (Tursiops truncatus) off Trinidad, Stenella sp. off Guyana and Guiana dolphin (Sotalia guianensis) at the entrance of the Suriname River. Opportunistic records originating from the periods December 2008-March 2009 and August-October 2012 were forwarded to the author. These records included common bottlenose dolphin, Atlantic spotted dolphin (Stenella frontalis) and short-finned pilot whale (Globicephala macrorhynchus).

There is a growing need to identify critical areas for marine biodiversity conservation, both locally and regionally. This paper describes the general occurrence of the cetacean community encountered in Suriname waters in summer. The study revealed that the offshore cetacean community in Suriname is best described as primarily a tropical community, dominated by odontocetes (dolphins and sperm whales). Although the species diversity was relatively high, the overall cetacean relative abundance index (number of animals per 100km effort) was low, which is consistent for tropical equatorial offshore waters. Apart from the sperm whale and the Guiana dolphin, all the other species recorded represent new species records for Suriname. It is recommended that more continuous monitoring in different seasons be carried out in order to gain a better understanding of the occurrence, distribution and status of the different cetacean species within the region.

Resumo. Pouca informação encontra-se disponível acerca de cetáceos nas Guianas: Suriname e seus países vizinhos, Guiana e Guiana Francesa. Durante um levantamento dedicado de cetáceos conduzido a partir de uma embarcaçáo de sísmica nas águas de mar aberto do Suriname (maio-setembro 2012), a ocorrência de 13 espécies de cetáceos foi documentada, sendo 11 delas novos registros para aquela área. As espécies observadas pela autora incluíram cachalote (Physeter macrocephalus), baleiade-bryde (Balaenopter edeni), falsa-orca (Pseudorca crassidens), golfinho-cabeça-de-meláo (Peponocephala electra), golfinho-dedentes-rugosos (Steno bredanensis), golfinho-comum-de-bico-longo (Delphinus capensis), golfinho-de-fraser (Lagenodelphis hosei), golfinho-pintado-pantropical (Stenella attenuata) e golfinho-rotador (Stenella longirostris). Durante o deslocamento à área de levantamento (Trinidad ao Suriname), avistagens incidentais foram registradas, incluindo golfinho-nariz-de-garrafa-comum (Tursiops truncatus) em águas de Trinidad, Stenella sp. em águas da Guiana e boto-cinza (Sotalia guianensis) na entrada do Rio Suriname. Registros oportunísticos dos períodos dezembro 2008 a março 2009 e agosto-outubro 2012 foram 
encaminhados ao autor. Esses registros incluíram golfinho-nariz-de-garrafa-comum, golfinho-pintado-do-atlântico (Stenella frontalis) e baleia-piloto-de-peitorais-curtas (Globicephala macrorhynchus).

Existe uma necessidade crescente de identificar áreas críticas para a conservação da biodiversidade marinha, tanto a nível local quanto regional. Este artigo descreve a ocorrência geral da comunidade de cetáceos encontrada em águas do Suriname durante o verão. O estudo revelou que a comunidade de cetáceos de mar aberto do Suriname é melhor descrita como primariamente uma comunidade tropical, dominada por odontocetos (golfinhos e cachalotes). Embora a diversidade de espécies seja relativamente alta, o índice geral de abundância relativa de cetáceos (número de animais por $100 \mathrm{~km}$ de esforço) foi baixo, o que é consistente para águas de mar aberto tropical equatorial. Exceto pelo cachalote e pelo boto-cinza, todas as demais espécies observadas representam novos registros para o Suriname. Recomenda-se a conduçáo de monitoramento contínuo adicional em diferentes estaçóes do ano, a fim de se obter um melhor entendimento da ocorrência, distribuição e status das diferentes espécies de cetáceos na região.

\section{Introduction}

A total of 31 cetacean species occur within the Wider Caribbean Region (WCR) but there is a marked lack of records in the Guianas (Sub-Region VI of the WCR, see Figure 1), which includes the countries of Guyana, Suriname and French Guiana ${ }^{1}$ (Weir et al., 2011; Mannocci et al., 2013). The mammals of Suriname were listed by Husson (1978) and included six cetacean species that were either sighted in Suriname coastal waters or were found stranded. These were sperm whale (Physeter macrocephalus), Guiana dolphin (Sotalia guianensis), minke whale (recorded as Balaenoptera bonaerensis and Balaenoptera acutorostrata), fin whale Balaenoptera physalus) and sei whale (Balaenoptera borealis; Husson, 1978). The cetacean community is also under-recorded in the neighboring countries [French Guiana (Mannocci et al., 2013) and Guyana ${ }^{2}$. Recent aerial surveys reported the presence of cetaceans in French Guiana, including fin whale, sperm whale, Cuvier's beaked whale (Ziphius cavirostris), short-finned pilot whale (Globicephala macrorhynchus), Risso's dolphin (Grampus griseus), common bottlenose dolphin (Tursiops truncatus) and Guiana dolphin (Mannocci et al., 2013). In contrast, more detailed records exist for Venezuela in the southern Caribbean region (Romero et al., 2001; Bolaños-Jiménez and Villarroel-Marín, 2003; Bermúdez-Villapol and Boher, 2003). Apart from a recent study on the Guiana dolphin ${ }^{3}$, cetacean research has been lacking for Suriname. The scarcity of cetacean records for Suriname can therefore be attributed to a lack of survey effort rather than an absence of marine mammals.

During the past two decades, awareness of marine mammals and their habitats in the WCR has increased (Hoyt, 2011). The Specially Protected Areas and Wildlife (SPAW)

${ }^{1}$ Ward, N., Moscrop, A. and Carlson, C. (2001) Elements for the development of a marine mammal action plan for the wider Caribbean: a review of marine mammal distribution. First Meeting of the Contracting Parties (COP) to the Protocol Concerning Specially Protected Areas and Wildlife (SPAW) in the Wider Caribbean Region, Havana, Cuba. 83 pp. ${ }^{2}$ Kalamandeen, M. and Chesney, P. (2013) Marine Mammals of Guyana. Presented at the Marine Mammal Conservation Corridor for Northern South America workshop, Paramaribo, Suriname, 18-20 March 2013. ${ }^{3}$ M. Pool, pers. comm., 18 March 2013.
Protocol, the regional agreement for biodiversity and for the advancement of the conservation and protection of the marine environment in the WCR, became international law in June $2000^{4}$. A specific marine mammal action plan was adopted in 2008 under the framework of the United Nations Environment Programme's (UNEP) Caribbean Environment Programme with the aims to provide training workshops on stranding response and networking, whale- and dolphinwatch training, and implementation of a regional manatee conservation plan (Hoyt, 2011). This has also resulted in an increase in conservation management action in the Guianas and neighboring countries along northeastern Latin America, ranging from northern Brazil to Venezuela, including Trinidad and Tobago and the 'ABC islands' (Aruba, Bonaire, Curaçao) of the Dutch Caribbean'.

The objectives of the study were to describe: (1) the occurrence of cetaceans in Suriname offshore waters; (2) their relative abundance; and (3) species diversity. In addition, we present information on anecdotal records for Suriname and adjacent waters. This study provides a list of cetacean species that have been recorded in Suriname waters. These baseline data can be used for future investigations and monitoring as well as for conservation and management of cetaceans in the Guianas.

\section{Materials and Methods \\ Study Area}

Suriname is located on the northeast coast of South America, bordering the Atlantic Ocean, with French Guiana to the east, Guyana to the west and Brazil to the southeast (Figure 1). The Guianas and the Eastern Venezuelan Atlantic

\footnotetext{
${ }^{4}$ UNEP, United Nations Environment Program (2012) Report on the implementations of activities in support of the action plan for the conservation of marine mammals in the Wider Caribbean Region. $7^{\text {th }}$ Meeting of the Contracting Parties to the Protocol Concerning Specially Protected Areas and Wildlife (SPAW) in the Wider Caribbean Region, Punta Cana, Dominican Republic, 23 October 2012. 5 pp.

${ }^{5}$ Brichet, M. (2012) Workshop 5: North East of South America, Regional Cooperation for a Marine Mammals Conservation Strategy Workshop - MAMA COCO SEA Project, in Proceedings of the second International Conference on Marine Mammal Protected Areas. ICMMPA 2: Endangered Spaces, Endangered Species, 7-11 November 2011, Fort-de-France, Martinique.
} 


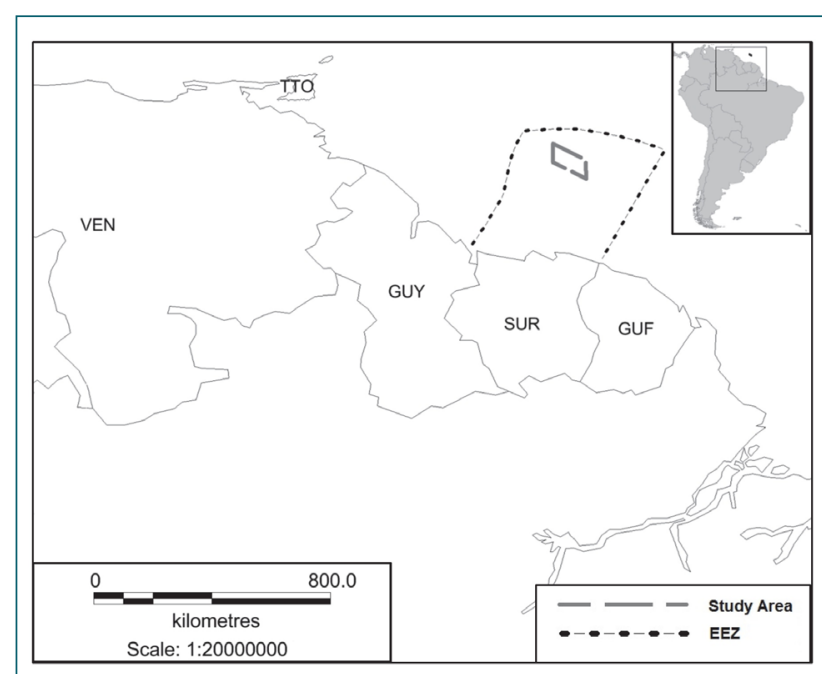

Figure 1. The Guianas: Guyana (GUY), Suriname (SUR) and French Guiana (GUF), Venezuela (VEN) and Trinidad and Tobago (TTO). The study area is shown in grey, and the outline of the Exclusive Economic Zone (EEZ) is also shown (some parts of the EEZ between Guyana and Suriname are disputed).

Front (also known as the Guiana Shield) are under the influence of the Amazon River. The typical ecosystems include estuaries, mudflats, sandy beaches, and mangrove forests, which extend along most of the largely unexplored coastline (Miloslavich et al., 2011). The tides along the coast of Suriname are semi-diurnal with tidal amplitudes ranging $1.3-2.3 \mathrm{~m}$. Sea surface temperatures (SST) are almost constant throughout the year $\left(27-29^{\circ} \mathrm{C}\right)$. Within the Guianas, the Guiana Current is the main current which is composed predominantly of the warm North Brazil Current which flows north along the northeastern coast of South America. Upon reaching French Guiana this current separates from the coast and joins the North Equatorial Countercurrent. The rest of the North Brazil Current continues flowing northwestward to form the Guiana Current (Condie, 1991). It is generally accepted that in Suriname's offshore areas the currents mainly flow from the southwest to the northeast quadrant and the highest current speeds are measured in April-May along the edge of the continental shelf 6 .

\section{Dedicated survey (effort-related)}

Dedicated (effort-related) cetacean observations were carried out within Suriname waters $\left(08^{\circ} 29^{\prime} \mathrm{N}, 54^{\circ} 41^{\prime} \mathrm{W}\right)$ between 17 May and 3 September 2012 during a geophysical seismic survey onboard the Western Regent. The 93.2m-long vessel acted as a platform of opportunity where the distribution of survey effort was determined by parallel survey transects $(n=114)$ designed for the geophysical activities. The only sightings recorded, and used in this study, were when the vessel did not deviate from the track-line. The vessel left Trinidad on 15 May and transited to the prospect area which extended between 220 and $300 \mathrm{~km}$ north of Paramaribo. There were three different survey periods (17 May-24 June;

${ }^{6}$ Gyory, J., Mariano, A. and Ryan, E. (2005) The Guiana Current. Ocean Surface Currents. Available online at <oceancurrents.rsmas.miami.edu/ atlantic/guinea.html>.

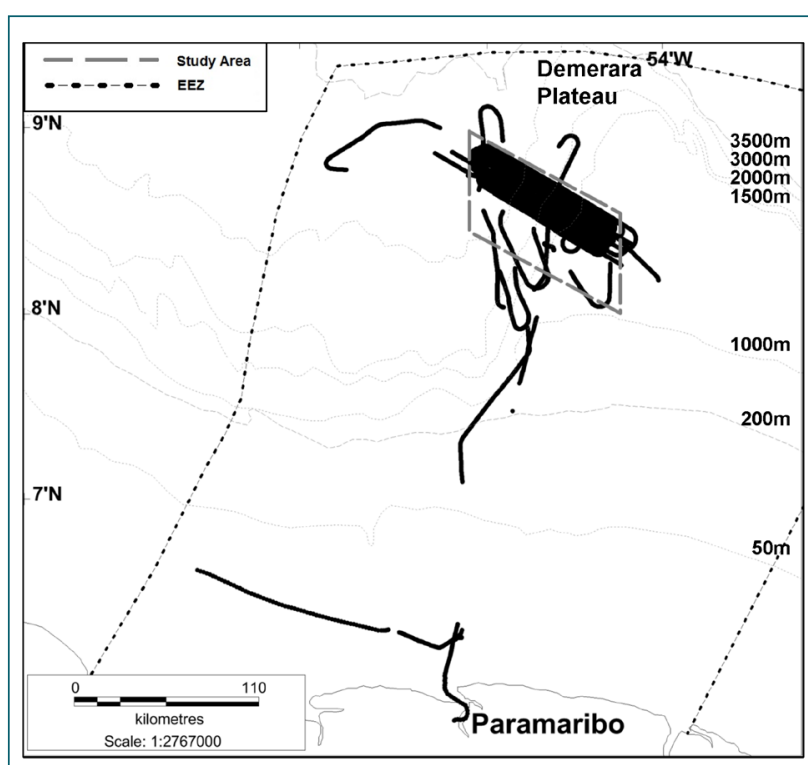

Figure 2. The main study area (in grey) where effort-related cetacean observations were carried out from a geophysical seismic survey vessel together with the GPS tracks (in black) within Suriname waters 17 May to 25 July 2012; some parts of the Exclusive Economic Zone between Guyana to the west and Suriname are disputed. No GPS tracks were available from 25 July onwards; however, effort-related observations continued from the survey vessel within the study area until 3 September 2012.

25 June-24 July; 25 July-3 September). The main survey area comprised of water depths between 1200-3600m and covered approximately $3000 \mathrm{~km}^{2}$ (Figure 2 ). The vessel operated with a speed over ground of $c a .4$ knots. Observations were carried out during all daylight hours (09:00-22:00 UTC). During the survey, teams of two observers carried out observations of either 1.5 or 2 hours duration. Observational effort was conducted from the bridge wings and foredeck at $14 \mathrm{~m}$ height with one observer monitoring ahead and to the port side of the vessel and the other observer watching ahead and to the starboard side. The observers scanned the sea predominately with the naked eye but used binoculars (8x43 and 10x42) for searching the horizon, aiding species identification and group-size estimations. Once a sighting was made the radial sighting distance was determined using person-specific rangesticks (Heinemann, 1981). The bearing to the sighted animals and their heading were estimated using the ship's mounted compasses which were positioned on both the starboard and portside bridge wings. Sightings data also included the time (UTC), GPS position, water depth, species identification, group-size and the presence of calves and/or subadults. DSLR cameras were used with zoom lenses (e.g. Sony 700alpha with a $200 \mathrm{~mm}$ f2.8 lens and a Canon EOS550D with a $100-400 \mathrm{~mm}$ f4.5-5.6 lens). Environmental observations were also collected during the survey, such as wind speed and direction (using the ship's wind meter), swell height and visibility (estimated by eye) and Beaufort sea state (BSS) according to the Beaufort scale. Water depth and SST were measured throughout the survey period (Acoustic Doppler Current Profiler data). A Garmin GPS (GPSMAP76CSx) was used to log the ship's position every 


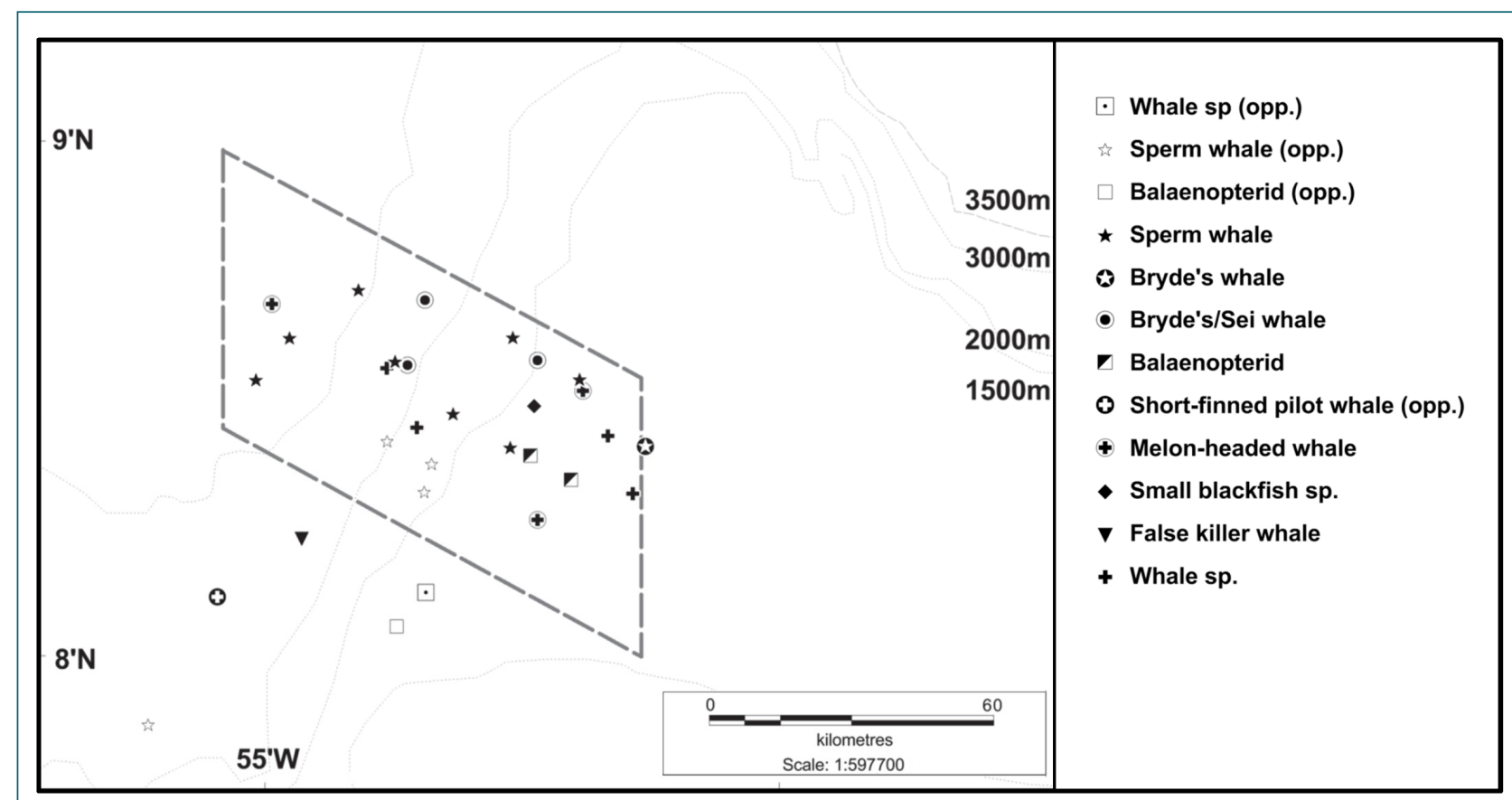

Figure 3. The main study area (in grey) and sighting positions of different whale and 'blackfish' species (see text) recorded during a dedicated cetacean survey carried out from a geophysical seismic survey vessel within Suriname offshore waters between 17 May and 3 September 2012 . Confirmed opportunistic records (opp.) contributed by various oil companies are also shown.

minute (Figure 2). During the third leg the author was not present; however, the two observers who were present on the first leg were again present during the third leg. All observers had previous experience of conducting cetacean surveys in tropical waters. Global positioning system, speed and course data were not continuously logged during the third leg; however, information on effort was provided as hours on watch.

\section{Species categories}

The tall, falcate dorsal fins of Bryde's whales (Balaenoptera brydeiledeni; e.g. Notarbartolo di Sciara ${ }^{7}$ ) are easily confused with those of sei whales. Baleen whales too distant from the vessel to allow definite identification $(>1 \mathrm{~km})$ were therefore classed as 'balaenopterid' (i.e. large rorqual with vertical blow and well-defined fin; definitely not blue or humpback whale) or 'Bryde's/Sei whale' (i.e. large rorquals with prominent, upright and falcate dorsal fin). Depending on sighting distance and glare intensities, similar looking dolphins were classed as follows: Stenella/Delphinus sp. (definitely one of the five Stenella species: pantropical spotted, Atlantic spotted, spinner, clymene, striped and/or Delphinus species); 'Stenella sp.' (i.e. definitely a Stenella species with a mid-length beak: pantropical spotted, Atlantic spotted, clymene or striped; but definitely not spinner dolphin or long-beaked common dolphin); 'spinner/clymene sp.' (i.e. small active dolphins seen

${ }^{7}$ Notarbartolo di Sciara, G.N. (1983) Bryde's whales (Balaenoptera edeni Anderson 1878) offeastern Venezuela (Cetacea Balaenopteridae). Hubbs Sea World Research Institute, Technical Report 83-153. 15 pp. 'spinning' and likely to be one of these two species); or 'small blackfish sp.' (melon-headed whale or pygmy killer whale). All other unidentified animals were classed as 'dolphin sp.' or 'whale sp.'

\section{Data analysis (effort-related)}

The data in the present study are not suitable to estimate the abundance of species because the survey track-lines fail to provide equal coverage probability (e.g. Buckland et al., 2001). Instead, the relative abundance (or encounter rate) was measured and expressed as the number of individuals per $100 \mathrm{~km}$ effort $(\mathrm{BSS} \leq 4$, swell $\leq 4 \mathrm{~m}$, visibility $\geq 1 \mathrm{~km})$. However, these relative abundances were only calculated for legs 1-2 for which detailed GPS tracks were available.

The bearing and distance to sightings were used to estimate the position of each sighting taking into account the location of the vessel at the time of the sighting and the observation eye-height (using the GEOFUNC Software with spherical trigonometry functions ${ }^{8}$ ). All GPS records were imported into MapInfo Geographic Information System (v. 11) using the projection WGS84.

To estimate species diversity, the Shannon-Wiener index was calculated. Only sightings which were identified to species level were used (Ricklefs, 2007): $\mathrm{H}=-\Sigma P i * \operatorname{Ln} P i$, where $\mathrm{H}$ is a measure of diversity and $P i$ is the proportion of individuals belonging to species $i$.

${ }^{8}$ NOAA National Oceanic and Atmospheric Administration - National Marine Mammal Laboratory (2013) Software - Excel Geometry Functions. Available online at <www.afsc.noaa.gov/nmml/software/excelgeo.php>. Consulted on 1 March 2013. 


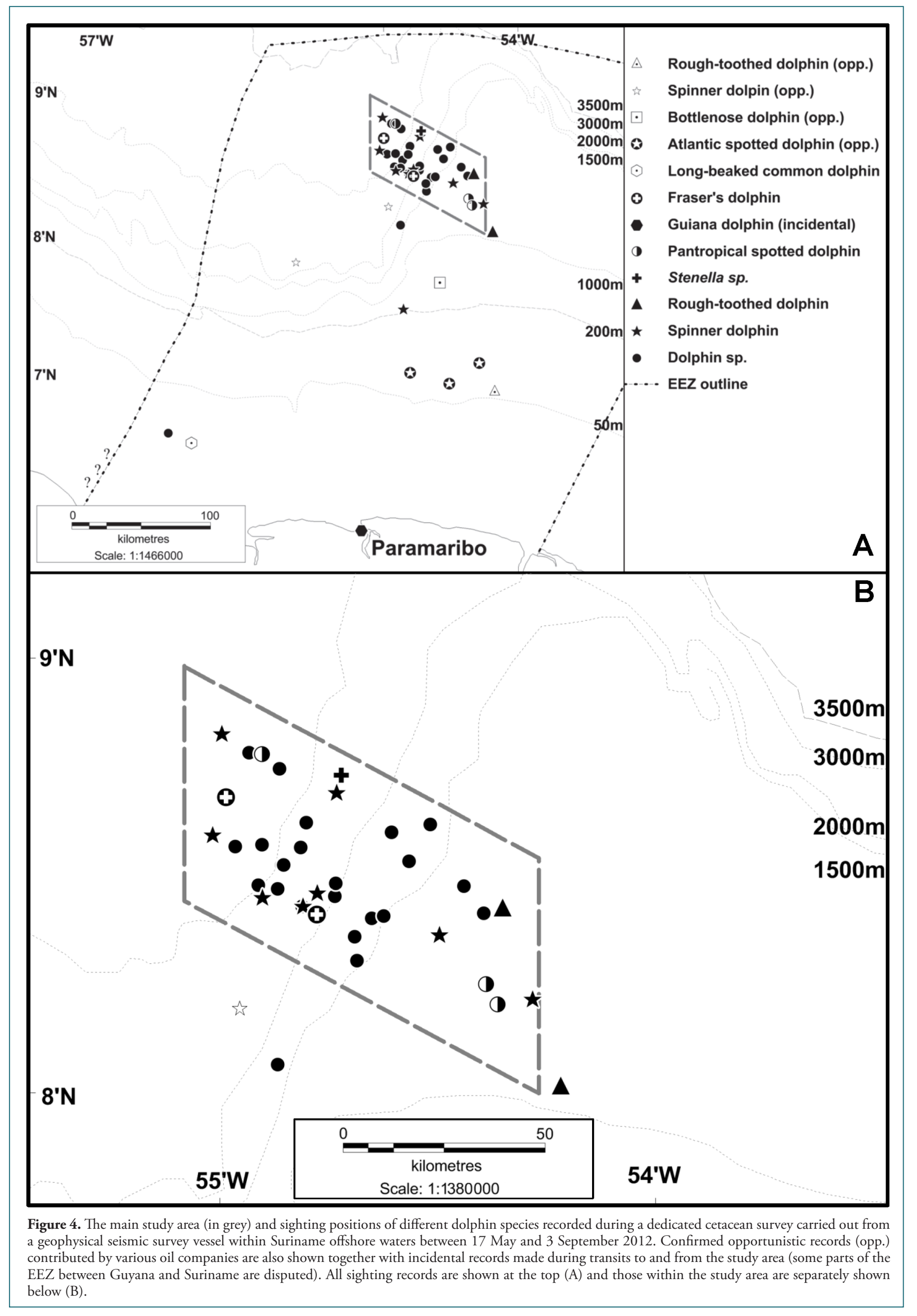


Table 1. Summary of cetacean sightings and number of animals $(\mathrm{N})$ recorded during the dedicated (effort-related) survey in Suriname (Legs 1-3), including information regarding incidental sightings recorded during transit to and from the study area. Those incidental sightings recorded in the waters of Trinidad/Guyana are marked $(*)$. Opportunistic records (non-effort related at-sea sightings forwarded by oil companies) and strandings $(\dagger)$ previously recorded in Suriname are also listed.

\begin{tabular}{|c|c|c|c|c|c|c|c|}
\hline Species & $\begin{array}{l}\text { All sightings } \\
\text { (n) }\end{array}$ & $\begin{array}{c}\text { S } \\
(\mathbf{n})\end{array}$ & $\begin{array}{l}\text { S } \\
(\mathbf{n})\end{array}$ & $\begin{array}{c}S \\
(n)\end{array}$ & $\begin{array}{l}\text { Incidental } \\
\text { Sightings } \\
\text { (n) }\end{array}$ & $\begin{array}{c}\text { Relative } \\
\text { Abundance } \\
\text { Index (encounter } \\
\text { rate } \\
\text { n/100km) }\end{array}$ & $\begin{array}{l}\text { Opportunistic } \\
\text { Records and } \\
\text { Strandings } \dagger \\
\text { (n) }\end{array}$ \\
\hline Cetacean species & Leg 1-3 & Leg 1 & Leg 2 & Leg 3 & Leg1-3 & Leg1-2 & Other \\
\hline Balaenoptera physalus & - & - & - & - & - & -- & $\begin{array}{l}2 \dagger \\
(2)\end{array}$ \\
\hline Balaenoptera edeni & $1(1)$ & $1(1)$ & - & - & - & 0.016 & - \\
\hline Balaenoptera borealis & - & - & - & - & - & -- & $\begin{array}{l}1 \dagger \\
(1)\end{array}$ \\
\hline Sei/Bryde’s whale & $3(5)$ & $1(3)$ & $2(2)$ & - & - & 0.082 & - \\
\hline Balaenopterid & $2(2)$ & - & $2(2)$ & - & - & 0.033 & $3(4)$ \\
\hline B. acutorostrata/bonaerensis & - & - & - & - & - & -- & $\begin{array}{l}2 \dagger \\
(2)\end{array}$ \\
\hline Balaenoptera bonaerensis & - & - & - & - & - & -- & $\begin{array}{l}1 \dagger \\
(1)\end{array}$ \\
\hline Physeter macrocephalus & $\begin{array}{c}8 \\
(67) \\
\end{array}$ & $\begin{array}{c}1 \\
(20)\end{array}$ & $\begin{array}{c}5 \\
(38) \\
\end{array}$ & $\begin{array}{c}2 \\
(9) \\
\end{array}$ & - & 0.955 & $\begin{array}{c}4,1 \dagger \\
(27,1 \dagger)\end{array}$ \\
\hline Globicephala macrorhynchus & - & - & - & - & - & -- & $\begin{array}{c}1 \\
(8)\end{array}$ \\
\hline Pseudorca crassidens & $1(3)$ & - & $\begin{array}{c}1 \\
(3)\end{array}$ & - & - & 0.049 & - \\
\hline Peponocephala electra & $\begin{array}{c}3 \\
(520)\end{array}$ & $\begin{array}{c}1 \\
(120)\end{array}$ & $\begin{array}{c}1 \\
(200)\end{array}$ & $\begin{array}{c}1 \\
(200)\end{array}$ & - & 5.269 & - \\
\hline Small Blackfish sp. & $1(30)$ & - & $1(30)$ & - & - & 0.494 & - \\
\hline Stenella longirostris & $\begin{array}{c}9 \\
(410)\end{array}$ & - & $\begin{array}{c}4 \\
(155)\end{array}$ & $\begin{array}{c}5 \\
(255)\end{array}$ & $\begin{array}{c}1 \\
(5)\end{array}$ & 2.552 & $\begin{array}{c}2 \\
(250)\end{array}$ \\
\hline Stenella attenuata & $\begin{array}{c}3 \\
(290)\end{array}$ & - & $\begin{array}{c}1 \\
(60)\end{array}$ & $\begin{array}{c}2 \\
(230)\end{array}$ & - & 0.988 & - \\
\hline Stenella frontalis & - & - & - & - & - & -- & $\begin{array}{c}3 \\
(65)\end{array}$ \\
\hline Lagenodelphis hosei & $\begin{array}{c}2 \\
(90)\end{array}$ & - & $\begin{array}{c}1 \\
(30)\end{array}$ & $\begin{array}{c}1 \\
(60)\end{array}$ & - & 0.494 & - \\
\hline Delphinus capensis & $\begin{array}{c}1 \\
(50) \\
\end{array}$ & $\begin{array}{c}1 \\
(50) \\
\end{array}$ & - & - & - & 0.823 & - \\
\hline Steno bredanensis & $\begin{array}{c}2 \\
(65)\end{array}$ & - & $\begin{array}{c}1 \\
(40)\end{array}$ & $\begin{array}{c}1 \\
(25)\end{array}$ & - & 0.659 & $\begin{array}{c}1 \\
(3)\end{array}$ \\
\hline Tursiops truncatus & - & - & - & - & $\begin{array}{c}1^{*} \\
(14)\end{array}$ & -- & $\begin{array}{c}1 \\
(10)\end{array}$ \\
\hline Sotalia guianensis & - & - & - & - & $\begin{array}{c}2 \\
(13)\end{array}$ & - & (Resident) \\
\hline Stenella sp. & $1(30)$ & - & $1(30)$ & - & $1,1^{*}(4,4)$ & 0.494 & - \\
\hline 'Dolphin sp.' & $\begin{array}{c}24 \\
(582) \\
\end{array}$ & $6(123)$ & $6(85)$ & $12(374)$ & $\begin{array}{c}1,3^{*} \\
\left(2,19^{*}\right) \\
\end{array}$ & 3.425 & - \\
\hline 'Whale sp.' & $4(4)$ & $1(1)$ & $2(2)$ & $1(1)$ & - & 0.049 & $2(3)$ \\
\hline Total & $65(2149)$ & $\begin{array}{c}12 \\
(318)\end{array}$ & $28(677)$ & $25(1154)$ & $\begin{array}{c}10 \\
(61)\end{array}$ & 16.38 & $\begin{array}{c}17,7 \dagger \\
(370,7 \dagger)\end{array}$ \\
\hline
\end{tabular}



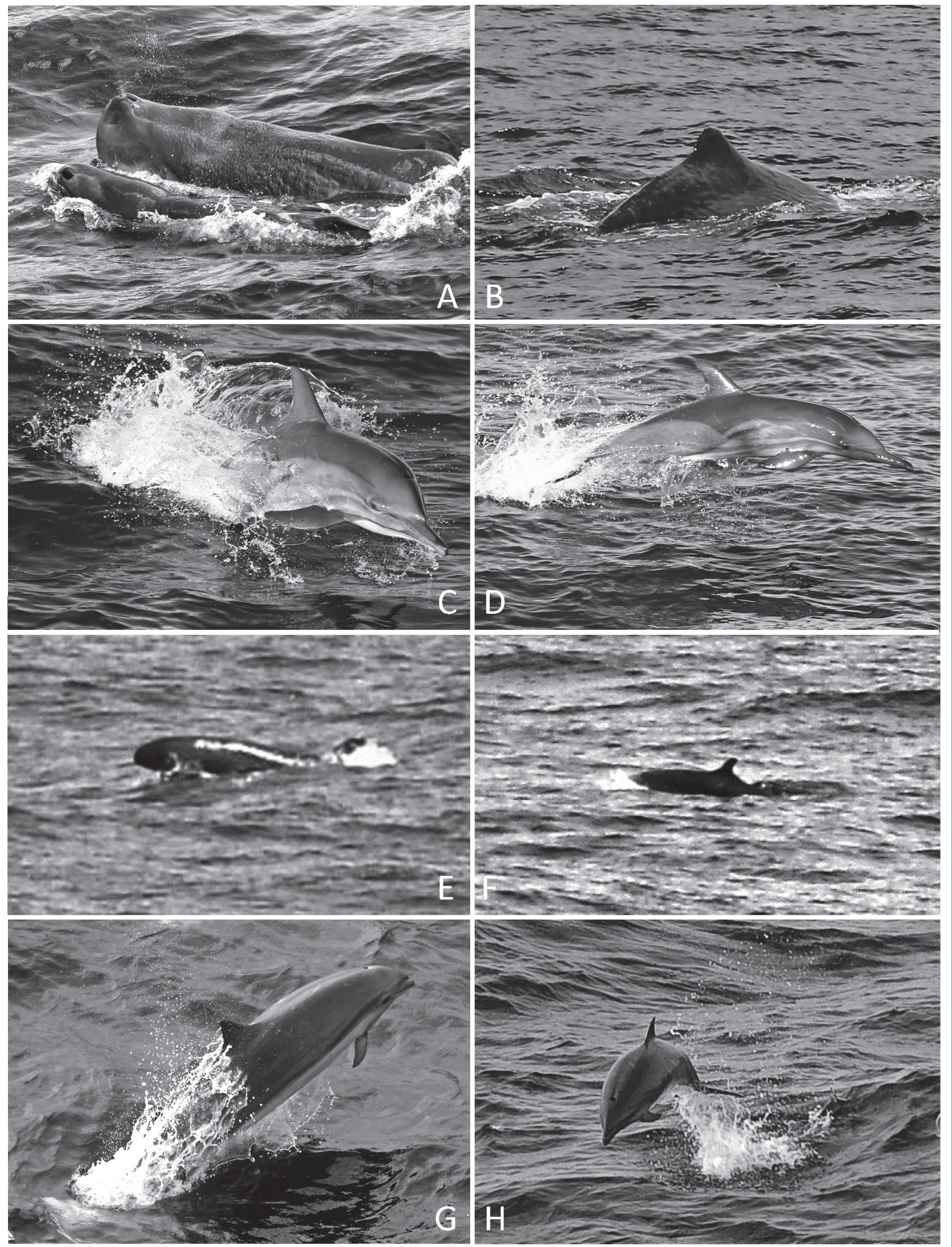

Figure 5. Photographs of sperm whale (Physeter macrocephalus) with calf

(A), adult sperm whale (B), long-beaked common dolphin (Delphinus capensis; C-D), false killer whale (Pseudorca crassidens; E-F) and Fraser's dolphin (Lagenodelphis hosei; G-H). Photographs (C M. de Boer (A, C-F, H), J. Saulino (B) and A. Williams (G). 


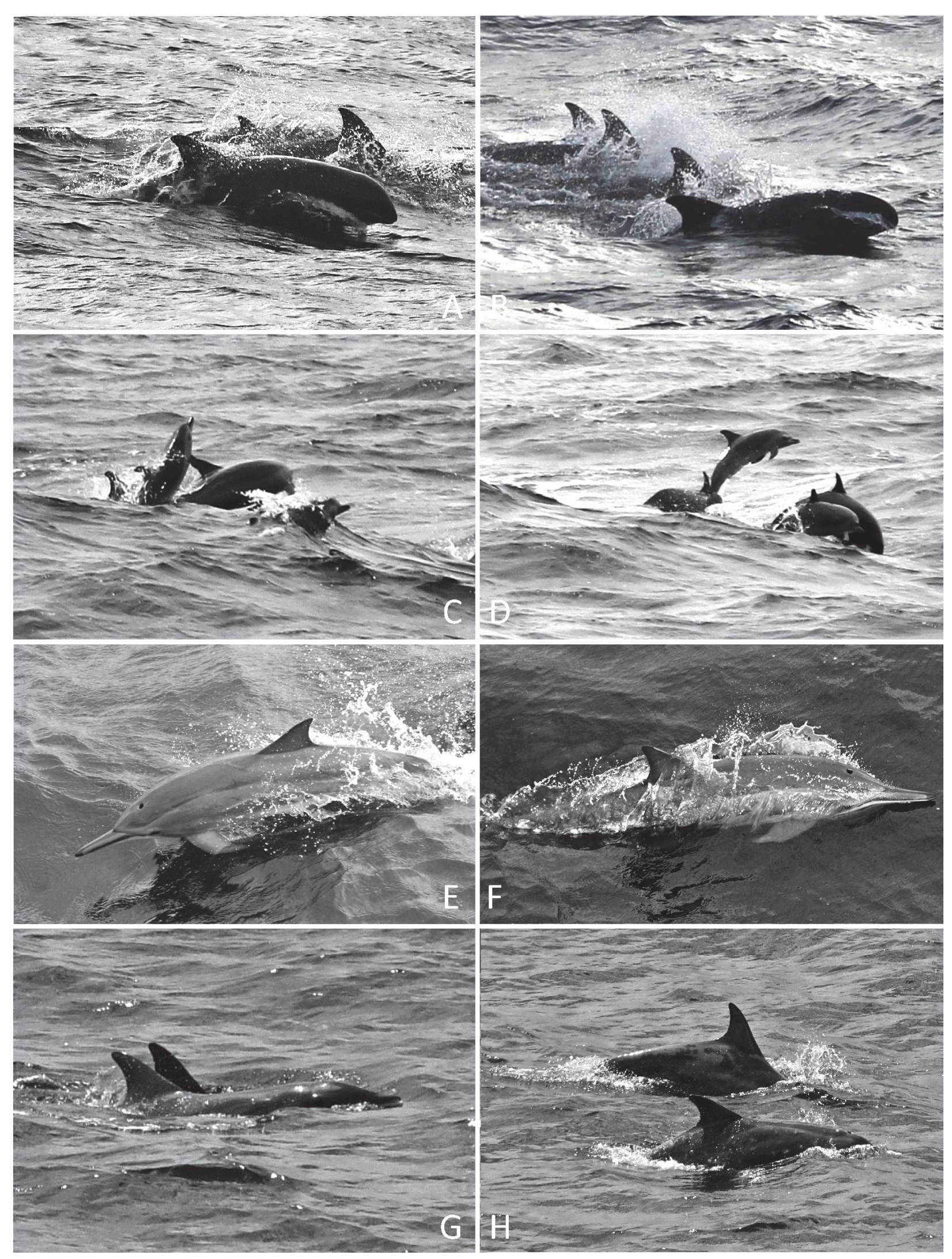

Figure 6. Photographs of melon-headed whale (Peponocephala electra; A-B), pantropical spotted dolphins (Stenella attenuata) with calf (C-D), spinner dolphin (Stenella longirostris; E-F) and rough-toothed dolphins (Steno bredanensis; G-H). Photographs (C) M. de Boer (E-H) and A. Williams (A-D). 

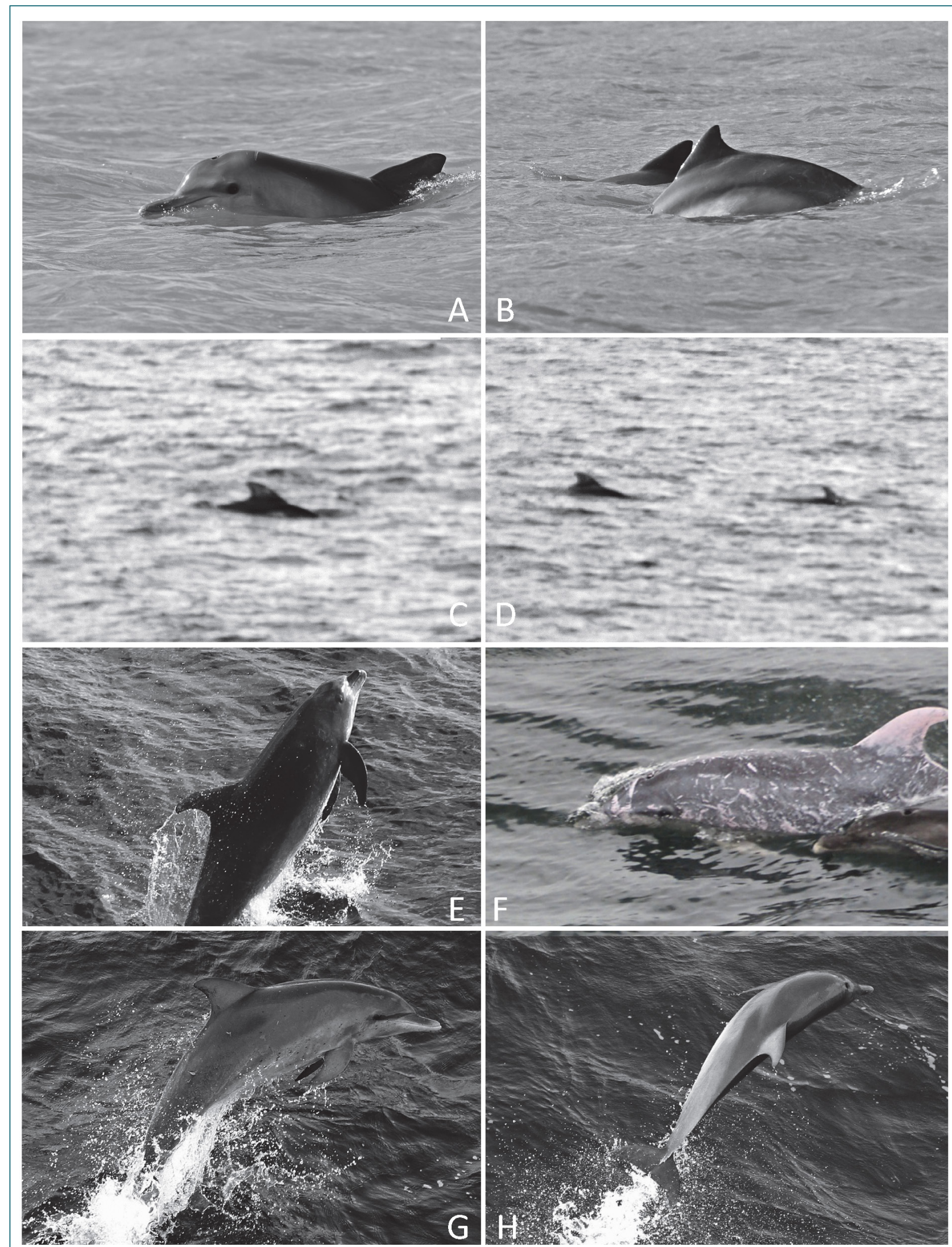

Figure 7. Photographs of Guiana dolphin (Sotalia guianensis; A-B), shortfinned pilot whale (Globicephala macrorhynchus; C-D), bottlenose dolphin (Tursiops truncatus; E-F) and Atlantic spotted dolphin (Stenella frontalis; G-H) in Suriname. Photographs (C) M. de Boer (A-B, E-H) and F. Penin (C-D). 


\section{Incidental sightings (off-effort)}

Cetacean sightings recorded during transit or those recorded when conditions were poor (i.e. BSS $>4$, swell > $4 \mathrm{~m}$ and visibility $<1 \mathrm{~km}$ ) were regarded as incidental (i.e. 'off-effort'). The species identification was checked and verified using written descriptions and photographs.

\section{Opportunistic records (not effort-related)}

Oil companies were contacted to request information about observed cetaceans within Suriname waters. These opportunistic records were integrated into the analysis only when verifying information in the form of photographs was available. Specimens of stranded cetaceans were inspected at the National Zoological Collection of Suriname (NZCS) in Paramaribo.

\section{Results}

\section{Dedicated survey (effort-related)}

A total of $1268 \mathrm{hrs}$ of observational effort were carried out in fair weather conditions (BSS 0-4, swell $\leq 4 \mathrm{~m}$ and visibility $\geq 1 \mathrm{~km}$ ). During Leg 1 a total of $389 \mathrm{hrs}$ of effort $(2922 \mathrm{~km})$ and during Leg 2 a total of $376 \mathrm{hrs}$ of effort $(3151 \mathrm{~km})$ were carried out. During the third leg a total of $503 \mathrm{hrs}$ of effort were carried out. A total of 68 effort-related sightings and 2152 animals were recorded. An additional 10 incidental sightings were also recorded (Table 1). A total of $44.1 \%$ of sightings remained unidentified $(n=30)$ due to their distance from the vessel. In addition, $11.8 \%$ of sightings were identified to species categories (i.e. similar looking species; $\mathrm{n}=8$ ). During transits (Trinidad to Suriname) a total of five incidental sightings were recorded. Whilst off Trinidad these included a sighting with 14 bottlenose dolphins and one with unidentified dolphins and whilst off Guyana, a further two sightings were recorded involving 'dolphin sp.' and a group of four Stenella sp. (Table 1). The dedicated survey was carried out in waters with depths of $1000-2000 \mathrm{~m}$ (51.3\%) whilst $1.4 \%$ was carried out in waters with depths $<1000 \mathrm{~m}$, $35 \%$ between $2000-3000 \mathrm{~m}$ and $12.2 \%>3000 \mathrm{~m}$. The SSTs recorded during the survey ranged from 26 to $30^{\circ} \mathrm{C}$ (mean $28.3^{\circ} \mathrm{C}$ ). The SSTs were the highest between 11 June and 22 July and again between 16-24 August. The vessel was in seismic operation for $57.2 \%$ of the visual effort and data presented here are potentially influenced by unknown reactions of cetaceans to seismic operations. The species richness during the dedicated survey was nine. The Shannon-Wiener diversity index was 1.62 for the whole survey period.

The different species encountered and the species categories are described below. The sightings are depicted in Figures 3 and 4 and photographic evidence for each species can be found in Figures 5 to 7 .

Bryde's whale (Balaenoptera edeni): The taxonomic status of Bryde's whale is complex and B. edeni is used here to refer to this species?. Three sightings of Bryde's/Sei whale were recorded, one sighting was confirmed as Bryde's whale through acoustic recordings and two balaenopterids were seen at close distances (i.e. at $400 \mathrm{~m}$ a juvenile, and at $700 \mathrm{~m}$ an adult). The confirmed Bryde's whale was seen in waters with a depth of $1225 \mathrm{~m}$ whilst the other whales were seen in 1217$2241 \mathrm{~m}$ water depth. All baleen whales were sighted between 14 June and 19 July.

Sperm whale (Physeter macrocephalus): Sperm whales were the most abundant whale species $(0.955$ ind./100km; Table 1). An estimated 67 animals (including several subadults, at least three calves and no adult males) were seen in waters with an average depth of $2152 \mathrm{~m}(\mathrm{SD}=711.4 \mathrm{~m}$; range $=1293$ $2974 \mathrm{~m}$ ) between June-August. The group sizes ranged from two to 20. On one occasion, a small calf was seen making several short peduncle dives, behavior which has been described as indicative of suckling ${ }^{10}$.

Melon-headed whale (Peponocephala electra): Three sightings were made of melon-headed whales involving 485 animals (28 subadults, 7 calves). They were associating with Fraser's dolphins (Lagenodelphis hosei) and floating mats of Sargassum. This species was seen in 1191-3063m water depth and sightings occurred on 9 June (120 animals), 28 June (200 animals) and 30 July (200 animals).

False killer whale (Pseudorca crassidens): On 13 July, a group of three false killer whales was photographed in $2444 \mathrm{~m}$ water depth.

Rough-toothed dolphin (Steno bredanensis): Rough-toothed dolphins were seen on two occasions: a) 1 July: water depth $1018 \mathrm{~m}$, group size 40 and b) 24 August: water depth $1241 \mathrm{~m}$, group size 25 . The group sighted on 1 July was observed for almost one hour and included one subadult and one calf.

Fraser's dolphin (Lagenodelphis hosei): Fraser's dolphins were sighted on two occasions (28 June and 20 August). The first record was a group of at least 30 to 40 dolphins which were associating with a group of melon-headed whales (water depth: $3063 \mathrm{~m}$ ). The second encounter involved at least 60 dolphins, not associated with other species (water depth: $2100 \mathrm{~m}$ ).

Common bottlenose dolphin (Tursiops truncatus): One incidental sighting of common bottlenose dolphin was recorded off Trinidad. The group of 14 was briefly bow-riding the vessel (water depth: $48 \mathrm{~m}$ ). One adult displayed a large degree of scarring and was unusually pale and pinkish in colour (Figure $7 \mathrm{~F})$. This species was also recently recorded and photographed by the author in the coastal waters of Suriname (June 2013; Figure 7E).

${ }^{9}$ IUCN, International Union for Conservation of Nature (2013) Status of the world's cetaceans. IUCN-SSC Cetacean Specialist Group. Available online at <www.iucn-csg.org/index.php/status-of-the-worlds-cetaceans/>. Consulted on 18 July 2013.

${ }^{10}$ Gero, S. and Whitehead, H. (2006) Opportunistic sightings of small cetaceans off the leeward shore of the Commonwealth of Dominica. Paper SC/58/SM1 presented at the $58^{\text {th }}$ annual meeting of the Scientific Committee of the International Whaling Commission, St Kitts and Nevis, 16-20 June 2006. 
Pantropical spotted dolphin (Stenella attenuata): Three encounters were recorded with pantropical spotted dolphins in $1140-3043 \mathrm{~m}$ water depth (11 July, 7 and 10 August) with group sizes ranging from 30 to 200.

Spinner dolphin (Stenella longirostris): Eight sightings of spinner dolphins were recorded between 11 July and 3 September and one incidental sighting was recorded during transit on 25 July whilst heading back to Paramaribo. The dolphins were seen in waters with a mean depth of $2251 \mathrm{~m}$ $(\mathrm{SD}=720.95, \mathrm{n}=8$, range $=1154-3094 \mathrm{~m})$ but the incidental sighting occurred in waters with a depth of $200 \mathrm{~m}$. The group size ranged between 5-100 animals (at least 14 subadults and four calves).

Stenella sp.: Two sightings were recorded involving Stenella sp. and one sighting was recorded off Guyana on 16 May in 78.6m water depth.

Long-beaked common dolphin (Delphinus capensis): On 17 May long-beaked common dolphins were observed whilst in transit between Trinidad and Suriname at a distance of $66 \mathrm{~km}$ from the coast (water depth: $35.8 \mathrm{~m}$ ). This species was also recently recorded and photographed by the author in the coastal waters of Suriname (June 2013; Figure 5C-D).

Guiana dolphin (Sotalia guianensis): The Guiana dolphin was seen on two occasions at the mouth of the Suriname River during transits to and from the study area.

\section{Opportunistic records (not effort-related)}

A total of 17 opportunistic records were accepted which related to the periods December 2008-March 2009 and August-October 2012 (Table 1; Figures 2-3).

Mysticetes: Two sightings with large whales were recorded as humpback whale (Megaptera novaeangliae) in October 2012. However, no photographs were available to confirm species and these sightings were therefore classed as 'whale sp.'. Three sightings of unidentified large balaenopterids were recorded on 2 October 2012 (water depth: 1282-1776m).

Odontocetes: Sperm whales were recorded in September 2012, totaling four confirmed sighting records of 27 animals. Short-finned pilot whales (Globicephala macrorhynchus) were recorded on 7 September 2012 in 2549m water depth (Figure 7). Rough-toothed dolphins were recorded once in shallow waters (49m) in January 2009. Two sightings of spinner dolphins were recorded in the months of August and September (water depths: 1946-1974m). One sighting involving bow-riding bottlenose dolphins was recorded on 8 October 2012 in $451 \mathrm{~m}$ water depth. Three sightings of Atlantic spotted dolphin (Stenella frontalis) were recorded between December 2008 and March 2009. The water depths ranged between 57 and $72 \mathrm{~m}$. This species was also recently recorded on several occasions by the author in the coastal waters of Suriname (June 2013; Figure 7G-H).

\section{Discussion}

Records of cetacean species in Suriname waters were anecdotal and this study confirmed the presence of 13 species, of which 11 are new species records for Suriname. The most abundant species were the sperm whale and melon-headed whale. It was found that the spinner dolphin and pantropical spotted dolphin were also frequently encountered in large groups. The relative abundance index for all cetaceans (16.38 inds $/ 100 \mathrm{~km}$ ) was relatively low as was expected considering the survey was confined to deep water only (1200-3300m). When comparing these estimates to other systematic surveys in tropical regions in the east Atlantic, off Gabon in west Africa, the estimates were found to be much higher in areas which spanned both deep and shallow waters (20.9 inds $/ 100 \mathrm{~km}$; De Boer, 2010). Indeed, tropical shallow shelf waters, for example off the Maldives in the Indian Ocean, generally hold a much more diverse and abundant cetacean community (35.3 inds $100 \mathrm{~km}$; Clark et al., 2012).

The diversity of cetaceans, as measured by the ShannonWiener index, was relatively high (1.62). This index assumes that all species are represented in a sample and that they are randomly sampled (Ricklefs, 2007). This is difficult to achieve with the current survey design; however, the four months duration of the dedicated study together with the systematic transect lay-out probably increased our chances of recording different species. The present index is similar to those presented for Aruba (1.29) by Luksenburg (2013). Various other studies have used the Shannon-Wiener index to measure local diversity of cetaceans (Dulau-Drouot et al., 2008; Gannier, 2009; Kizka et al., 2010); however, comparison with the present study is hampered by differences in spatial and temporal sampling effort among survey areas.

Caution is also required because overt responses to the seismic sound source by some cetacean species may have occurred. For example, responses by short-finned pilot whales and Atlantic spotted dolphin were documented off west Africa $^{11}$ (Weir, 2008a, b).

\section{Species accounts}

Mysticetes: Bryde's whales off the north coast of Venezuela (Oleson et al., 2003) have low frequency calls with a specific frequency of $44 \mathrm{~Hz}$ which was close to those recorded during the present detection (a $40 \mathrm{~Hz}$ signal was located in approximately the same position where the whale was seen at the time of the sighting ${ }^{12}$. This species is the only baleen whale present year-round in significant numbers within the $\mathrm{WCR}^{13}$

\footnotetext{
${ }^{11}$ Cerchio, S., Collins, T., Strindberg, S., Bennett, C. and Rosenbaum, H. (2010) Humpback whale singing activity off northern Angola: an indication of the migratory cycle, breeding habitat and impact of seismic surveys on singer number in breeding stock B1. Paper SC/62/SH12 presented at the $62^{\text {nd }}$ annual meeting of the Scientific Committee of the International Whaling Commission, Agadir, Morocco, 21-25 June 2010.

${ }^{12}$ De Boer, M.N., Riechelt, M., Saulino, J., Williams, A., Baines, M. and Lewis, T. (2012) Marine Fauna Report to Tullow Oil. Unpublished Report n ${ }^{\circ}-6$, RPS Energy, Axminster, UK. 5 pp.

${ }^{13}$ Reeves, R.R. (2005) Insights of marine mammals of the Wider Caribbean Sea Region (including the Gulf of Mexico) derived from whaling history documents. Pages 1-9 in Proceedings of the Regional Workshop of Experts on the Development of the Marine Mammal Action Plan for the Wider Caribbean Region, 18-21 July 2005, Bridgetown, Barbados.
} 
and especially in the southern Caribbean (e.g. Notarbartolo di Sciara7; Debrot et al., 1998; Romero et al., 2001). No other sightings or stranding records of Bryde's whales are known for Suriname or adjacent waters; however, they are common in Venezuela (Romero et al., 2001; Acevedo-Galindo, 2007). The distribution of Bryde's whales appears to be seasonal with whales occurring mainly to the east between March and August whilst from August to December the whales occur further west ${ }^{7}$. This might explain the lack of sightings in the present survey from August onwards. In the coastal waters off central Venezuela, the Bryde's whale can be present between October and February ${ }^{14}$ (Acevedo-Galindo, 2007).

Odontocetes: Sperm whales were seen regularly and most frequently in the vicinity of the Demerara Plateau. In the northeast of the Caribbean, sperm whales are strongly seasonal and are rarely seen from April through September (MignucciGiannoni, 1998). In the southeast of the Caribbean, between November and March, sperm whales are consistently found (Ward et al., 2001). Sightings and strandings of sperm whales have also been reported off Venezuela (Bolaños-Jiménez and Villarroel-Marín, 2008a). Three at-sea sightings were reported for French Guiana in October (Mannocci et al., 2013). The present study highlights that this species is relatively abundant between June and September and that it uses the area for breeding/nursing.

Melon-headed whales were recorded in deep waters throughout this survey and within the region this species occurs in the Gulf of Mexico, off the Lesser Antilles and Dominica (Ward et al., 2001). A mixed group of melon-headed whales and Fraser's dolphins was reported off Carriacou ${ }^{15}$. Records exist for Puerto Rico and Venezuela (Mignucci-Giannoni, 1998; Bolaños-Jiménez and Villarroel-Marín, 2003).

False killer whales were seen only once and the distribution of this species in the Caribbean is poorly known (Ward et al., 2001). In the southern part of the Caribbean, it has been reported in Colombia (Alberico et al., 2000; Pardo et al., 2009), Aruba (Luksenburg, 2011) and the coastal waters of Venezuela (Bermúdez-Villapol and Boher, 2003; Romero et al., 2001).

Short-finned pilot whales were recorded on only one occasion in September yet this species is regarded as very common in the Caribbean (Ward et al., 2001). Off French Guiana this species was recorded regularly in October

\footnotetext{
${ }^{14}$ Bolaños-Jiménez, J., Guada, H. and Lentino, M. (2007) 7. Fauna

Relevante. Pages 120-133 in Martín, A., Malavé, L., Sánchez, D., Aparicio, R., Arocha, F., Bone, D., Bolaños, J.A., Bolaños-Jiménez, J., Castañeda, J., Cárdenas, J.J., Carbonini, A.K., Díaz, Y.J., Guada, H.J., Klein, E., Lazo, R., Lemus, A., Lentino, M., Lira, C., Lodeiros, C., López, R., Marín, B., Martínez, G., Márquez, B., Márquez, A., Molinet, R., Morales, F., Posada, J., Prieto, A., Riera, A., Rodríguez, C.T., Ramírez, A., Senior, W., Solana, P., Severeyn, H., Spiniello, P.,Valera, E., Yanes, E. and Zoppi, E., Eds (2007) Línea base ambiental plataforma Deltana. Petróleos de Venezuela, S.A., Caracas, Venezuela.

${ }^{15}$ IFAW, International Fund for Animal Welfare (1996) Cetacean field research conducted from Song of the Whale off Dominica and Grenada: Spring 1996. IFAW, Yarmouth Port, USA. 17 pp.
}

(Mannocci et al., 2013) and also during boat-based surveys (September-December 2009) ${ }^{16}$. Pilot whales have also been recorded in Venezuela but only in the eastern waters (e.g. Romero et al., 2001).

Rough-toothed dolphins were observed on three occasions and this species is generally regarded as uncommon in the Caribbean with reports for the Gulf of Mexico, the West Indies, Colombia, Venezuela (e.g. Romero et al., 2001) and off Aruba (Luksenburg, 2013). Off French Guiana this species was validated by Van Canneyt et al. ${ }^{17}$

Fraser's dolphins were encountered on two occasions yet no records for Suriname or adjacent waters currently exist. Within the Atlantic Ocean the reported number of sightings of Fraser's dolphins is low (e.g. Hersh and Odell, 1986; Weir et al., 2013). Records exist from the Puerto Rican Bank (MignucciGiannoni et al., 1999), the Lesser Antilles including Dominica, St. Vincent, the Grenadines ${ }^{18}$ (Caldwell et al., 1976) and the Gulf of Mexico (Würsig et al., 2000). Other sightings, offshore Guadaloupe, offshore Carriacou and offshore La Martinique have also been reported ${ }^{15,19,20,21}$. Recently, Fraser's dolphins were reported off the leeward shore of Dominica ${ }^{10}$ and offshore Montserrat (Weir et al., 2011). Within the region, two dolphins stranded in Venezuela (June 1999; Bolaños-Jiménez and Villarroel-Marín, 2003) and one dolphin stranded on Bonaire (August 2011; Witte et al., 2012).

Common bottlenose dolphins were recorded twice and are generally described as common in the coastal waters and outer edge of the continental shelf in the Gulf of Mexico and in the waters of the Caribbean and southwards to Venezuela and Brazil (Swartz and Burks, 2000; Ward et al., 2001). In the Venezuelan Atlantic, near Trinidad and Tobago, this species has been observed in mixed aggregations with Atlantic spotted dolphin ${ }^{14}$. Bottlenose dolphins were reported in high densities in the continental slope zone off French Guiana (Mannocci et al., 2013) and probably regularly occur within the Guiana Shield.

${ }^{16}$ Vines, J., Teixeira, M. and Paixão, I. (2010) Marine mammal observer's report during Guiana Maritime 3D/2D seismic survey, RPS Energy, Axminster, UK. 30 pp.

${ }^{17}$ Van Canneyt, O., Certain, G., Doremus, G., Laran, S., Ridoux, V., Bolańos, J., Jeremie, S. and Watremez, P. (2009) Distribution and abundance of marine megafauna in French Guiana, REMMOA Campaign Guiana. CRMM, La Rochelle, France. 41 pp.

${ }^{18}$ ECCN, Eastern Caribbean Cetacean Network (2000) Stranding and sightings database, Bequia, St. Vincent and the Grenadines, West Indies. ${ }^{19}$ Boisseau, O., Carlson, C.A. and Seipt, I. (2000) A report on cetacean research conducted by the International Fund for Animal Welfare (IFAW) off Guadeloupe, Dominica, Martinique, Grenada and Tobago from 12 January to 30 March 2000. Unpublished Report to IFAW, Yarmouth Port, USA. 17 pp.

${ }^{20}$ Rinaldi, C., Rinaldi, R. and Sahagian, P. (2006) Report of surveys conducted on small cetaceans off Guadeloupe 1998 to 2005. Paper SC/58/ SM17 presented at the $58^{\text {th }}$ annual meeting of the Scientific Committee of the International Whaling Commission, St Kitts and Nevis, 16-20 June 2006.

${ }^{21}$ Jérémie, S., Gannier, A., Bourreau, S. and Nicolas, J.C. (2006) Cetaceans of Martinique Island (Lesser Antilles): occurrence and distribution obtained from a small boat dedicated survey. Paper SC/58/SM23 presented at the $58^{\text {th }}$ annual meeting of the Scientific Committee of the International Whaling Commission, St Kitts and Nevis, 16-20 June 2006. 
Atlantic spotted dolphins were recorded only in shallow waters during this survey and no previous records for Suriname or adjacent waters currently exist. Off Venezuela, the species is widespread in both inshore and offshore waters (Romero et al., 2001; Acevedo-Galindo, 2007), in Colombia it is found to be more common than pantropical spotted dolphins (Vidal, 1990; Pardo and Palacios, 2006) and this species was recently recorded off Aruba (Luksenburg, 2013).

Pantropical spotted dolphins were recorded in deep waters $(>1000 \mathrm{~m})$ and this species has been reported off the Dominican Republic, Dominica, St. Vincent and the Grenadines, St. Lucia, Tobago, Colombia (Ward et al., 2001) and the ABC Islands (Debrot et al., 1998) but only one record is known for Venezuela (eastern sector; Romero et al., 2001). Confirmed at-sea sightings were reported off French Guiana between September-December $2009^{16}$.

Spinner dolphins were sighted regularly and mainly in deep waters and commonly occur in the Caribbean, the Gulf of Mexico, and throughout the West Indian chain southwards to Venezuela (Würsig et al., 2000). The species has also been recorded in the Bahamas, Cuba, Puerto Rico, Dominica, St. Vincent, the Grenadines and the Caribbean in general (e.g. Jefferson and Lynn, 1994; Romero et al., 2001). The species also occurs off the $\mathrm{ABC}$ Islands and they are fairly common off Venezuela (Debrot et al., 1998; Romero et al., 2001; Acevedo-Galindo, 2007; Luksenburg, 2011).

Long-beaked common dolphins were recorded on one occasion in shallow waters and this species commonly occurs along the eastern coasts of Venezuela in areas with coastal upwelling 22 (Romero et al., 2001). A recent review by Jefferson et al. (2009) shows that the species is expected to occur off the Guianas. The only reliable records are of a long-beaked common dolphin captured off Trinidad in April 200623, a stranding in the Gulf of Paria (Oviedo et al., 2010), a sighting off Aruba (Luksenburg, 2013), and recently the species was validated for French Guiana ${ }^{17}$, central-western Venezuela ${ }^{22}$ and Colombia (Palacios et al., 2012). The species has not been confirmed to occur in most of the Caribbean Sea, i.e. Central America, Greater Antilles or West Indies (Jefferson et al., 2009).

Guiana dolphins were recorded at the entrance of the Suriname River. This coastal species is the most frequently encountered cetacean in Suriname which may swim up rivers, particularly during the dry season, when the saltwater incursion is further upriver and the salinity is high enough (Gómez-Salazar et al., 2010). Recently, causes for concern were raised regarding dolphin displacement following river seismic activities in Suriname (Pool, 2012). The Guiana dolphin is known to be incidentally killed in gillnets at the

\footnotetext{
${ }^{22}$ Bolaños-Jiménez, pers. comm., 18 December 2014.

${ }^{23}$ Boisseau, O., Leaper, R. and Moscrop, A. (2006) Observation of small cetaceans in the eastern Caribbean. Paper SC/58/SM24 presented at the $58^{\text {th }}$ annual meeting of the Scientific Committee of the International Whaling Commission, St Kitts and Nevis, 16-20 June 2006.
}

mouths of the Suriname and Coppename rivers and also in French Guiana ${ }^{24}$ (Husson, 1978; Van Waerebeek, 1990; Vidal et al., 1994). The Guiana dolphin is listed as vulnerable in Venezuela (Bolaños-Jiménez et al., 2008) and its status in Suriname has yet to be established.

\section{Previous records for Suriname}

Several cetacean species have previously been reported in Suriname waters (Husson, 1978; Table 1).

Mysticetes: A stranding of a sei whale was recorded in 1964 in northwestern Suriname (Husson, 1978) and the skull of this specimen was recently examined by the author at the National Zoological Collection of Suriname (NZCS) in Paramaribo. It was concluded that the skull probably was that of a sei whale ${ }^{25}$. There are a few records for sei whales in the Caribbean and the species is considered rare ${ }^{7}$ (Romero $e t$ al., 2001).

Two or three records of fin whale are reported for Suriname in 1910 and 1923 (Husson, 1978). The baleen morphology as shown in Husson (1978) seems to be consistent with that of the fin whale although physical inspection of the baleen would be required to exclude other large rorquals $s^{25}$. The author could not locate the fin whale specimens at the NZCS. There are a few records for fin whales for the Caribbean (Slijper et al., 1964), for Colombia (Prieto Rodríguez, 1988; Vidal, 1990); Venezuela $^{26}$ (Swartz and Burks, 2000; Romero et al., 2001) and the Gulf of Mexico (Jefferson and Schiro, 1997). On the basis of a stranding in August and a sighting in March, Bolaños-Jiménez and Villarroel-Marín (2008b) speculated that Venezuelan waters could be visited by fin whales coming from both the northern and southern hemispheres. More recently, fin whales were sighted off French Guiana during aerial surveys in October 2008 (Mannocci et al., 2013).

The skeleton of a minke whale (unknown stranding date) was collected around 1923 or 1924 near Coppename Punt in Suriname and identified by Husson (1978) as Balaenoptera acutorostrata. However, the identification cannot be verified, as insufficient voucher material is available. More recently, another minke whale stranded in Suriname (approximately 12 years $\mathrm{ago}^{27}$ ), but no associated data appear to exist. Only occasional records of common minke whale are known for the northeastern Caribbean (Rice, 1998). Another record of minke whale involved an animal seen swimming in the Coppename River in October 1963 which was subsequently killed and identified as Antarctic minke whale B. bonaerensis (Husson, 1978). This specimen showed a wide, conspicuous dark band along the outer margin of the baleen plates which

\footnotetext{
${ }^{24}$ Plouvier, D., Gomes, L., Verweij, P. and Verlinden, N. (2012) Living Guianas. WWF-Guyana Report. 84 pp.

${ }^{25}$ K. Van Waerebeek, pers. comm., 22 May 2013.

${ }^{26}$ Lira, C., Bolańos, J. and Mondolfi, E. (1995) On two strandings of fin whale (Balaenoptera physalus) and its presence in Venezuelan waters. Page 169 in Abstracts, XI Biennial Conference on the Biology of Marine Mammals, 18-21 December 1995, Orlando, Florida, USA.

${ }^{27}$ P. Oubote, pers. comm., 15 March 2013.
} 
Table 2. List of cetaceans occurring off Venezuela, Suriname and French Guiana, including strandings $(\dagger)$, sightings ( $\mathrm{x})$ and those expected to occur based on records elsewhere within the Wider Caribbean Region.

\begin{tabular}{|c|c|c|c|c|}
\hline Species & Latin name & Venezuela & Suriname & French Guiana \\
\hline Humpback whale & Megaptera novaeangliae & $\mathrm{x}$ & (unconfirmed) & $\mathrm{x}$ \\
\hline Fin whale & Balaenoptera physalus & $\mathrm{x}$ & $\dagger ?$ & $\mathrm{x}$ \\
\hline Sei whale & Balaenoptera borealis & & $\dagger$ & \\
\hline Bryde's whale & Balaenoptera edeni & $\mathrm{x}$ & $\mathrm{x}$ & expected \\
\hline Common minke whale & Balaenoptera acutorostrata & & $\dagger$ & \\
\hline Antarctic minke whale & Balaenoptera bonaerensis & & $\dagger$ & \\
\hline Sperm whale & Physeter macrocephalus & $\mathrm{x}$ & $\mathrm{x}, \dagger$ & $\mathrm{x}$ \\
\hline Dwarf sperm whale & Kogia sima & $\mathrm{x}$ & expected & expected \\
\hline Pygmy sperm whale & Kogia breviceps & expected & expected & expected \\
\hline Cuvier's beaked whale & Ziphius cavirostris & $\mathrm{x}$ & expected & $\mathrm{x}$ \\
\hline Gervais' beaked whale & Mesoplodon europaeus & $\mathrm{x}$ & expected & expected \\
\hline Blainville's beaked whale & Mesoplodon densirostris & expected & expected & expected \\
\hline Killer whale & Orcinus orca & $\mathrm{x}$ & expected & $\mathrm{x}$ \\
\hline Pygmy killer whale & Feresa attenuata & $\mathrm{x}$ & expected & expected \\
\hline Melon-headed whale & Peponocephala electra & $\mathrm{x}$ & $\mathrm{x}$ & $\mathrm{x}$ \\
\hline False killer whale & Pseudorca crassidens & $\mathrm{x}$ & $\mathrm{x}$ & $\mathrm{x}$ \\
\hline Short-finned pilot whale & Globicephala macrorhynchus & $\mathrm{x}$ & $\mathrm{x}$ & $\mathrm{x}$ \\
\hline Risso's dolphin & Grampus griseus & $\mathrm{x}$ & expected & $\mathrm{x}$ \\
\hline Bottlenose dolphin & Tursiops truncatus & $\mathrm{x}$ & $\mathrm{x}$ & $\mathrm{x}$ \\
\hline Rough-toothed dolphin & Steno bredanensis & $\mathrm{x}$ & $\mathrm{x}$ & $\mathrm{x}$ \\
\hline Long-beaked common dolphin & Delphinus capensis & $\mathrm{x}$ & $\mathrm{x}$ & $\mathrm{x}$ \\
\hline Striped dolphin & Stenella coeruleoalba & $\mathrm{x}$ & expected & $\mathrm{x}$ \\
\hline Fraser's dolphin & Lagenodelphis hosei & $\mathrm{x}$ & $\mathrm{x}$ & expected \\
\hline Pantropical spotted dolphin & Stenella attenuata & $\mathrm{x}$ & $\mathrm{x}$ & $\mathrm{x}$ \\
\hline Atlantic spotted dolphin & Stenella frontalis & $\mathrm{x}$ & $\mathrm{x}$ & expected \\
\hline Spinner dolphin & Stenella longirostris & $\mathrm{x}$ & $\mathrm{x}$ & $\mathrm{x}$ \\
\hline Clymene dolphin & Stenella clymene & expected & expected & expected \\
\hline Guiana dolphin & Sotalis guianensis & $\mathrm{x}$ & $\mathrm{x}, \dagger$ & $\mathrm{x}$ \\
\hline
\end{tabular}

Data sources: Husson, 1978; Romero et al., 2001; Ward et al., 2001; Bolańos and Villarroel-Marín, 2003; Van Canneyt et al., 2009; Vines et al., 2010; Mannocci et al., 2013; this study.

were recently inspected and photographed by the author at the NZCS in Paramaribo. The coloration and morphology of the baleen as shown by the photos are consistent with those of the Antarctic minke whale ${ }^{25}$. A specimen of $B$. bonaerensis recently recorded in Togo (Gulf of Guinea, western Africa) led Segniagbeto and Van Waerebeek ${ }^{28}$ to conclude that this species may at least occasionally cross the Equator into the Northern Hemisphere.
${ }^{28}$ Segniagbeto, G. and van Waerebeek, K. (2010) A note on the occurrence and status of cetaceans in Togo. Paper SC/62/SM11 presented at the $62^{\text {nd }}$ annual meeting of the Scientific Committee of International Whaling Commission, Agadir, Morocco. 21-25 June 2010. 
Odontocetes: A sperm whale stranded in 1938 was described by Husson (1978). The Guiana dolphin was originally described by P.J. Van Bénéden in 1864 based on dolphins taken at the mouth of the Marowijne (Maroni) River (Husson, 1978), i.e. at the border area between French Guiana and Suriname.

\section{Species Inventory}

An inventory of the cetacean species for Suriname and those previously documented within the Guiana Shield and along the Venezuelan Atlantic region is shown in Table 2 and shows that Suriname has a species rich and diverse cetacean fauna. It is expected that increased future survey effort expanding to shelf and coastal waters and carried out year-round will likely result in the identification of additional species, especially those that are known to occur elsewhere within the WCR. The survey described here can only provide a 'snap shot' view of the presence and distribution of cetaceans recorded during the months May-September (dedicated survey) and August-March (opportunistic records). The data show that the Suriname cetacean community is primarily composed of odontocetes (sperm whales and dolphins). Mysticetes, particularly large balaenopterids, were also observed although their occurrence was probably seasonal with Bryde's/Sei whales recorded only during June and July when the SSTs were reaching $30^{\circ} \mathrm{C}$. The opportunistic records highlighted that large baleen whales were recorded from early October and that shelf waters are probably more important for the dolphin community compared to deep waters.

Cetaceans are vulnerable to human-related threats in the WCR, including direct exploitation (removal from populations by live-captures), incidental bycatch in fishing gear (van Waerebeek, 1990; Vidal et al., 1994), habitat degradation or loss from coastal development, pollution, acoustic disturbances, unregulated whale-watching operations and vessel strikes (e.g. Reeves ${ }^{29}$; Borobia and Barros $^{30}$; Bolaños-Jiménez et al., 2007). Information on the occurrence of cetaceans in the Guianas is therefore vital to investigate and subsequently mitigate such potential threats. The listing of Protected Areas under the SPAW Protocol is under development ${ }^{4}$ and the present study therefore provides a timely overview of baseline data to inform UNEP's Marine Mammal Action Plan for the WCR. It is emphasized that more systematic at-sea surveys, photo-identification and behavioral studies are needed in order to assess the status of cetaceans and to develop effective regionally and nationally specific conservation measures not only in Suriname waters

\footnotetext{
${ }^{29}$ Reeves, R.R. (2005) Distribution and status of marine mammals of the wider Caribbean region: an update of UNEP documents. UNEP, Report UNEP (DEC)/CAR WG.27/INF.3. 8 pp.

${ }^{30}$ Borobia, M. and Barros, N.B. (2006) Major threats to small cetaceans in the Caribbean region: a summary report. Paper SC/58/SM15 presented at the $58^{\text {th }}$ annual meeting of the Scientific Committee of the International Whaling Commission, St Kitts and Nevis 16-20 June 2006.
}

but within the Guinea Shield as a whole. It is considered important and recommended that all research activities in this area document and report their opportunistic records, in order to gain a better understanding about the occurrence, distribution and ecology of cetacean species within the Guiana Shield.

\section{Acknowledgments}

I thank James Saulino, Andy Williams and Tim Lewis for their enthusiasm, support and contributing photographs. I thank all the other observers and in particular contributing photographers Stephanie Milne and Philipe Penin. Of equal importance has been the support and goodwill of the crews of the Western Regent, Geo Celtic and Ramform Sovereign. Many thanks to Dave Bolger and Nicole McMahon from Tullow Oil and Marny Daal-Vogelland from Staatsolie. Opportunistic records, which were gratefully received, were contributed by Murphy Oil, Kosmos Energy and Mary Jo Barkaszi (CSA Ocean Sciences). Many thanks to Koen Van Waerebeek regarding the identification of stranded specimens, Paul Ouboter and Rawien Jairam from the NZCS for assistance with the whale specimens and Steve Geelhoed and Peter Reijnders for reviewing an earlier draft of this manuscript. And finally, many thanks also to the anonymous reviewers whose efforts greatly improved this manuscript.

\section{References}

Acevedo-Galindo, R. (2007) Potential geographical distribution of seven species of marine cetaceans reported in Venezuela, Southeast Caribbean. Acta Zoologica Sinica 53(5): 853-864.

Alberico, M., Cadena, A., Hernandez-Camacho, J. and Muńoz-Saba, Y. (2000) Mamíferos (Synapsida: Theria) de Colombia. Biota Colombiana 1: 43-75.

Bermúdez-Villapol, L. and Boher, S. (2003) Lista actualizada de las especies de cetáceos de Venezuela. Boletín de la Sociedad Venezolana de Ciencias Naturales 153(XLVI): 113-118.

Bolaños-Jiménez, J. and Villarroel-Marín, A.J. (2003) Three new records of cetacean species for Venezuelan waters. Caribbean Journal of Science 39: 230-232.

Bolaños-Jiménez, J. and Villarroel-Marín, A.J. (2008a) Cachalote Physeter macrocephalus Linnaeus 1758. Page 114 in Rodríguez, J.P. and Rojas-Suárez, F. (Eds) Libro rojo de la fauna venezolana. Provita and Shell Venezuela S.A., Caracas, Venezuela.

Bolaños-Jiménez, J. and Villarroel-Marín, A.J. (2008b) Rorcual común Balaenoptera physalus Linnaeus 1758. Page 110 in Rodríguez, J.P. and Rojas-Suárez, F. (Eds) Libro rojo de la fauna venezolana. Provita and Shell Venezuela S.A., Caracas, Venezuela. 
Bolaños-Jiménez, J., Villarroel-Marín, A.J., Parsons, E. C.M. and Rose, N. (2007) Origin and development of whalewatching in the state of Aragua, Venezuela: Laying the groundwork for sustainability. Pages 16-27 in Lück, M., Gräupl, A., Auyong, J., Miller, M. and Orams, M. (Eds) Balancing marine tourism, development and sustainability. Proceedings of the V International Coastal and Marine Tourism Congress, 11-15 September 2007. School of Hospitality and Tourism, AUT University, the New Zealand Tourism Research Institute (NZTRI), and the School of Marine Affairs, University of Washington. Auckland, New Zealand.

Bolaños-Jiménez, J., Pirela, D., Rojas, J. and León, T. (2008) Bufeo negro, Sotalia guianensis Van Beneden 1863. Page 12 in Rodríguez, J. P. and Rojas-Suárez, F. (Eds) Libro rojo de la fauna de Venezuela. 3.ed. Provita and Shell Venezuela S.A., Caracas, Venezuela.

Buckland, S.T., Anderson, D.R., Burnham, K.P., Laake, J.L., Borcher, D.L. and Thomas, L. (2001) Introduction to distance sampling. Oxford University Press, New York, USA.

Caldwell, D.K., Caldwell, M.C. and Walker, R.V. (1976) First records for Fraser's dolphin (Lagenodelphis hosei) in the Atlantic and the melon-headed whale (Peponocephala electra) in the western Atlantic. Cetology 25:1-4.

Clark, R.A., Johnson, C.M., Johnson, G., Payne, R., Kerr, I., Anderson, R.C., Sattar, S.A., Godard, C.J. and Madsen, P.T. (2012) Cetacean sightings and acoustic detections in the offshore waters of the Maldives during the northeast monsoon seasons of 2003 and 2004. Journal of Cetacean Research and Management 12(2): 227-234.

Condie, S.A. (1991) Separation and recirculation of the north Brazil current. Journal of Marine Research 49: 1-19. http://dx.doi.org/10.1357/002224091784968620

De Boer, M.N. (2010) Cetacean distribution and relative abundance in offshore Gabonese waters. Journal of the Marine Biological Association of the United Kingdom 90(8): 16131621. http://dx.doi.org/10.1017/S0025315410001165

Debrot, A.O., De Meyer, J.A. and Dezentjé, P.J.E. (1998) An overview of the cetacean fauna of the Leeward Dutch Antilles. Caribbean Journal of Science 34: 204-210.

Dulau-Drouot, V., Boucaud, V. and Rota, B. (2008) Cetacean diversity off La Réunion Island (France). Journal of the Marine Biological Association of the United Kingdom 88: 1263-1272. http://dx.doi.org/10.1017/ S0025315408001069

Gannier, A. (2009) Comparison of odontocete populations of the Marquesas and Society Islands (French Polynesia). Journal of the Marine Biological Association of the United Kingdom 89: 931-941. http://dx.doi.org/10.1017/ S0025315408002713
Gómez-Salazar, C., Portocarrero-Aya, M., Trujillo, F., Caballero, S., Bolańos-Jiménez, J., Utreras, V., McGuire, F., Ferrer-Pérez, A., Pool, M. and Aliaga-Rossel, E. (2010) Update on the freshwater distribution of Sotalia in Colombia, Ecuador, Peru, Venezuela and Suriname. Latin American Journal of Aquatic Mammals 8(1-2): 171-178.

http://dx.doi.org/10.5597/lajam00166

Heinemann, D. (1981) A range finder for pelagic birds censusing. Journal of Wildlife Management 45(2): 489-493. http://dx.doi.org/10.2307/3807930

Hersh, S.L. and Odell, D.K. (1986) Mass strandings of Fraser's dolphin, Lagenodelphis hosei, in the western north Atlantic. Marine Mammal Science 2: 73-76.

http://dx.doi.org/10.1111/j.1748-7692.1986.tb00029.x

Hoyt, E. (2011) Marine protected areas for whales, dolphins and porpoises: a world handbook for cetacean habitat conservation. 2.ed. Earthscan, London, UK.

Husson, A.M. (1978) The mammals of Suriname. Zoölogische Monographieën van het Rijksmuseum van Natuurlijke Historie 2: $1-569$.

Jefferson, T.A. and Lynn, S.K. (1994) Marine mammal sightings in the Caribbean Sea and Gulf of Mexico, summer 1991. Caribbean Journal of Science 30: 83-89.

Jefferson, T.A. and Schiro, A.J. (1997) Distribution of cetaceans in the offshore Gulf of Mexico. Mammal Review 27: 27-50. http://dx.doi.org/10.1111/j.1365-2907.1997.tb00371.x

Jefferson, T.A., Fertl, D., Bolaños-Jiménez, J. and Zerbini, A.N. (2009) Distribution of common dolphins (Delphinus spp.) in the western Atlantic Ocean: a critical re-examination. Marine Biology 156: 1109-1124. http://dx.doi.org/10.1007/s00227-009-1152-y

Kizka, J., Ersts, P.J. and Ridoux, V. (2010) Structure of a toothed cetacean community around a tropical island (Mayotte, Mozambique Channel). African Journal of Marine Science 32: 543-551.

http://dx.doi.org/10.2989/1814232X.2010.538145

Luksenburg, J.A. (2011) Three new records of cetacean species for Aruba, Leeward Antilles, southern Caribbean. Marine Biodiversity Records 4: 1-4.

http://dx.doi.org/doi:10.1017/S1755267210001193

Luksenburg, J.A. (2013). The cetaceans of Aruba, southern Caribbean. Journal of the Marine Biological Association of the UK 94: 1161-1174.

http://dx.doi.org/10.1017/S0025315413000337

Mannocci, L., Monestiez, R., Bolaños, J., Doremus, G., Jérémie, S., Laran, S., Rinaldi, R., Van Canneyt, O. and Ridoux, V. (2013) Megavertebrate communities from two contrasting ecosystems in the western tropical Atlantic. Journal of Marine Systems 111: 208-222.

http://dx.doi.org/10.1016/j.jmarsys.2012.11.002 
Mignucci-Giannoni, A.A. (1998) Zoogeography of cetaceans off Puerto Rico and the Virgin Islands. Caribbean Journal of Science 34(3-4): 173-190.

Mignucci-Giannoni, A., Montoya-Ospina, A.R., Pérez-Zayas, J.J., Rodriguez-Lopez, M.A. and Williams, E.H. (1999) New records of Fraser's dolphin (Lagenodelphis hosei) for the Caribbean. Aquatic Mammals 25(1): 15-19.

Miloslavich, P., Klein, E., Díaz, J.M., Hernandez, C.E., Bigatti, G., Campos, L., Artigas, F., Castillo, J., Penchaszadeh, P.E., Neill, P.E., Carranza, A., Retana, M.V., Díaz de Astarloa, J.M., Lewis, M., Yorio, P., Piriz, M.L., Rodríguez, D., Yoneshigue-Valentin, Y., Gamboa, L. and Martín, A. (2011) Marine biodiversity in the Atlantic and Pacific coasts of South America: knowledge and gaps. PLOS One 6(1): e14631. http://dx.doi.org/10.1371/journal.pone.0014631

Oleson, E.M., Barlow, J., Gordon, J., Rankin, S. and Hildebrand, J.A. (2003) Low frequency calls of Bryde's whales. Marine Mammal Science 19(2): 407-419. http://dx.doi.org/10.1111/j.1748-7692.2003.tb01119.x

Oviedo, L., Esteves, M.A., Acevedo, R., Silva, N., BolañosJiménez, J., Quevedo, A.M. and Fernández, M. (2010) Abundance, distribution and behaviour of common dolphins, Delphinus sp., off north-eastern Venezuela: implications for conservation and management. Journal of the Marine Biological Association of the United Kingdom 90: 1623-1631. http://dx.doi.org/10.1017/S002531540999097X

Palacios, D.M., Herrera, J.C., Gerrodette, T., Garcia, C., Soler, G.A., Avila, I.C., Bessudo, S., Hernandez, E., Trujillo, F., Flórez-González, L. and Kerr, I. (2012) Cetacean distribution and relative abundance in Colombia's Pacific EEZ from survey cruises and platforms of opportunity. Journal of Cetacean Research and Management 12(1): 45-60.

Pardo, M.A. and Palacios, D.M. (2006) Cetacean occurrence in the Santa Marta region, Colombian Caribbean, 20042005. Latin American Journal of Aquatic Mammals 5: 129134. http://dx.doi.org/10.5597/lajam00105

Pardo, M.A., Jiménez-Pinedo, C. and Palacios, D.M. (2009) The false killer whale (Pseudorca crassidens) in the southwestern Caribbean: first stranding record in Colombian waters. Latin American Journal of Aquatic Mammals 7(1-2): 63-67. http://dx.doi.org/10.5597/lajam00136

Pool, M. (2012). River seismic survey in manatee habitat in Suriname. Sirenews-newsletter of the IUCN Sirenia Specialist Group 58: 14-17.

Prieto Rodríguez, M. (1988) Reporte de algunos cetáceos del Caribe Colombiano. Boletin de la Facultad de Biologia Marina, Universidad de Bogota Jorge Tadeo Lozano 8: 30-40.
Rice, D.W. (1998) Marine mammals of the world: Systematics and distribution. Special Publication No. 4. The Society for Marine Mammalogy, Lawrence, USA. 234 pp.

Ricklefs, R.E. (2007) The economy of nature. 5.ed. W.H. Freeman and Company, New York, USA.

Romero, A., Agudo, A., Green, S.M. and Notarbartolo di Sciara, G.N. (2001) Cetaceans of Venezuela: their distribution and conservation status. NOAA Technical Report NMFS, no. 151.

Slijper, E.J., Van Utrecht, W.L., and Naaktgeboren, C. (1964) Remarks on the distribution and migration of whales, based on observations from Netherlands ships. Bijdragen tot de Dierkunde 34:1-93.

Swartz, S.L. and Burks, C. (2000) Cruise results: windward humpback Megaptera novaeangliae survey. NOAA Ship Gordon Gunter, Cruise GU-00-01, 9 February to 3 April 2002. NOAA-NMFS-SEFSC Technical Memorandum 438. $31 \mathrm{pp}$.

Van Bénéden, P.J. (1864) Sur un dauphin nouveau (Delphinus guianensis) et un ziphoide rare. Mémoires de l'Académie Royale de Sciences de Belgique 16(1): 1-21.

Van Waerebeek, K. (1990) Preliminary notes on the existence of a dolphin by-catch off French Guiana. Aquatic Mammals 16:71-72.

Vidal, O. (1990) Lista de los mamíferos acuáticos de Colombia. Informe del Museo del Mar (Universidad Tadeo Lozano, Bogotá, Colombia) 37:1-18.

Vidal, O., Van Waerebeek, K. and Findley, L.T. (1994) Cetaceans and gillnet fisheries in Mexico, Central America and the Wider Caribbean: a preliminary review. Reports of the International Whaling Commission (Special Issue) 15: 221233.

Weir, C.R. (2008a) Overt responses of humpback whales (Megaptera novaeangliae), sperm whales (Physeter macrocephalus), and Atlantic spotted dolphins (Stenella frontalis) to seismic exploration off Angola. Aquatic Mammals 34: 71-83. http://dx.doi.org/10.1578/AM.34.1.2008.71

Weir, C.R. (2008b) Short-finned pilot whales (Globicephala macrorhynchus) respond to an airgun ramp-up procedure off Gabon. Aquatic Mammals 34: 349-354. http://dx.doi.org/10.1578/AM.34.3.2008.349

Weir, C.R., Calderan, S., Unwin, M. and Paulatto, M. (2011) Cetacean encounters around the island of Montserrat (Caribbean Sea) during 2007 and 2010, including new species state records. Marine Biodiversity Records 4: e42. http://dx.doi.org/10.1017/S1755267211000480 
Weir, C.R., Gonçalves, L. and May, D. (2013) New Gulf of Guinea (Africa) range state records for pygmy killer whale (Feresa attenuata) and Fraser's dolphin (Lagenodelphis hosei). Marine Biodiversity Records 6: e35.

http://dx.doi.org/10.1017/S1755267212001303
Witte, R.H., Van Buurt, G., Debrot, D.A., BermúdezVillapol, L.A. and Simal, F. (2012) First record of Fraser's dolphin Lagenodelphis hosei for the Dutch Caribbean. Marine Biodiversity Records 5: e46

http://dx.doi.org/10.1017/S1755267212000279 